\title{
Infection with human papillomaviruses of sexual partners of women having cervical intraepithelial neoplasia
}

\footnotetext{
R.L. Rombaldi ${ }^{1,3}$,

E.P. Serafini ${ }^{1,2}$, L.L. Villa ${ }^{5}$,

A.C. Vanni ${ }^{4}$, F. Baréa ${ }^{4}$,

R. Frassini ${ }^{4}$, M. Xavier ${ }^{4}$ and S. Paesi ${ }^{1}$
}

\author{
${ }^{1}$ Laboratório de Diagnóstico Molecular, Instituto de Biotecnologia, \\ ${ }^{2}$ Laboratório de Patologia Médica, Departamento de Ciências Biomédicas, \\ ${ }^{3}$ Ambulatório de Patologia do Trato Genital Feminino, Departamento de Clínica \\ Médica, ${ }^{4}$ Curso de Biologia, Universidade de Caxias do Sul, Caxias do Sul, RS, Brasil \\ ${ }^{5}$ Instituto Ludwig de Pesquisa Sobre o Câncer, São Paulo, SP, Brasil
}

\begin{abstract}
Correspondence
R.L. Rombaldi

Rua Humberto de Campos, 1055/402

95084-440 Caxias do Sul, RS

Brasil

Fax: +55-54-221-5677

E-mail: rl_rombaldi@brturbo.com.br

Publication supported by FAPESP.
\end{abstract}

$\ldots \ldots \ldots \ldots \ldots \ldots$

Received February 28, 2005

Accepted September 16, 2005

\begin{abstract}
Epidemiological studies show that human papillomaviruses (HPV) are strongly related to cervical cancer and cervical intraepithelial neoplasias (CIN). Unlike the case for women, there are no consistent data on the natural history of HPV in the male population even though these viruses are prevalent in males. We carried out a prospective study to assess the prevalence of HPV in males as well as the factors that determine such infections in 99 male sexual partners of women with CIN. The genitalia of the males were physically examined and subjected to peniscopy for the collection of scrapings which were subjected to the polymerase chain reaction and restriction fragment length polymorphism to detect HPV. Of the 99 males sampled, 54 (54.5\%) were positive for HPV DNA, 24\% of whom presented normal peniscopy, $28 \%$ presented evident clinical lesions and $48 \%$ isolated lesions consistent with subclinical infection. In the HPV-negative group, $53 \%$ showed normal peniscopy, $4 \%$ presented evident clinical lesions and $42 \%$ isolated lesions consistent with subclinical infection. The study detected a statistically significant association $(\mathrm{P}<0.02$, Pearson chi-square test) between HPV infection and both the mean number of sexual partners which a male had during his life and the mean number of sexual partners in the year prior to testing. Viral types 6 and 11 were most frequently encountered. The study shows that infection with HPV was frequent in male sexual partners of women with CIN.
\end{abstract}

\section{Introduction}

Infection with human papillomavirus (HPV), a non-culturable DNA virus of the family Papillomaviridae (1) has gained great importance during the last decade due to the recognition that this virus participates in the genesis of cervical cancer (2) and has high worldwide prevalence (3). More than 118
Key words

- Cervical intraepithelial

neoplasia

- Epidemiology

- Human papillomaviruses

- Polymerase chain reaction 
tory of HPV infection in males. A previous study (8) found that the prevalence of HPV in males ranged from 3.6 to $84 \%$ depending on the population and the methodology used, while it is also known (9-11) that the highest incidence (63 to $84 \%$ ) occurs in men attending clinics for the treatment of sexually transmitted diseases. There is a high prevalence $(10-85 \%)(12-17)$ of HPV lesions in the sexual partners of women with genital condyloma or cervical intraepithelial neoplasias (CIN) as compared with the $10 \%$ prevalence found in the general male population (18).

The present study determined the prevalence and the factors of HPV infection in an epidemiological survey of 99 male partners of women known to have CIN. Genital scrapings were submitted to the polymerase chain reaction (PCR) and restriction fragment length polymorphism (RFLP) to identify HPV carriers.

\section{Material and Methods}

\section{Population}

A prospective study was carried out at the University of Caxias do Sul (UCS, Caxias do Sul, RS, Brazil) between February 2003 and July 2004 on 99 male sexual partners of women with CIN. The study was approved by the UCS Ethics Research Committee. There was no conflict of interest for any of the authors. All subjects signed an informed consent form to participate in the study. The external genitalia of each male were examined physically before applying 5\% acetic acid for $5 \mathrm{~min}$ and examining the genital area and collecting scrapings using peniscopy. Peniscopic biopsies were obtained from areas suggestive of HPV infection.

\section{Epidemiological survey}

In the epidemiological survey we considered the following variables: age, age at first intercourse, circumcision, condom use with female sex workers, condom use with sexual partners, educational level, marital status, marital stability (number of years married), race, sexual intercourse with female sex workers, sexual partners up to the date of the survey, sexual partners in the year preceding the survey, sexually transmitted diseases, and tobacco smoking.

\section{Peniscopy}

Peniscopic images were classified as condylomatous lesions (acuminated, pigmented or non-pigmented warts), lesions suggestive of HPV infection (aceto-white areas, erythematous or macular lesions, papillomas or pearled papules) or normal.

\section{Sampling methods}

For each of the males studied a Urotest ${ }^{\circledR}$ brush was used to scrape the genitalia in the following sequence: urethral canal, areas identified by peniscopic images as being of clinical or subclinical significance regarding HPV, dorsal and ventral pre-glans region, preputial mucosa, and penile shaft. The brush was kept in TE solution $(10 \mathrm{mM}$ Tris hydrochloride, $\mathrm{pH} 7.5$, plus $1 \mathrm{mM}$ EDTA) at $2-4^{\circ} \mathrm{C}$ until the DNA was extracted. The scraping of the genitalia was performed after the peniscopy. Biopsies were taken from areas identified by peniscopic images as being of clinical or subclinical significance regarding HPV infection, a small piece of tissue being excised using a 'rattooth' forceps and an 'iris-curve' scissors. The excised material was fixed in $10 \%$ neutral formalin, embedded in paraffin and evaluated histologically, samples being considered HPV-positive when they exhibited cytoarchitectural signs suggesting koilocytotic lesion, HPV-negative when the histological evaluation was normal or showed non-specific chronic inflammation, and suggestive of HPV infection when histological examination showed alterations characteristic of 
hyper-keratinosis, hyperplasia, keratinization, or papillomatosis. Biopsy samples were checked by submitting them to a second evaluation by the same pathologist, who was aware of the result of the first diagnosis.

\section{Detection of HPV DNA}

Total viral DNA was extracted from the samples using a commercial kit (Puregene ${ }^{\mathrm{TM}}$ from buccal cells; Gentra Systems Inc., Minneapolis, MN, USA) and tested for HPV DNA using a PCR protocol which amplified a 450-bp segment of a conserved region of the L1 viral gene delineated by the MY9 and MY11 primers $(19,20)$. The reaction mixture contained $2 \mu \mathrm{L}$ of non-quantified extracted sample DNA in a final volume of $51 \mu \mathrm{L}$ containing $10 \mathrm{mM}$ Tris- $\mathrm{HCl}, \mathrm{pH} 8.3,5 \mathrm{mM}$ $\mathrm{MgCl}_{2}, 50 \mu \mathrm{M}$ of each dNTP, $0.4 \mu \mathrm{g}$ of each primer, and 1.75 units of Taq DNA polymerase (Invitrogen, Carlsbad, CA, USA). Before amplifying the sample DNA the quality of the host-cell DNA was evaluated using the $\mathrm{PCO}_{4}$ and $\mathrm{GH} 20$ primers (21) to amplify a 268-bp segment of the human ß-globulin gene. Amplification was carried out in a PTC100 thermocycler (MJ Research, Watertown, MA, USA) with 5 min for denaturation followed by 40 annealing cycles of $94^{\circ} \mathrm{C}$ for $30 \mathrm{~s}, 55^{\circ} \mathrm{C}$ for $1 \mathrm{~min}$ and $72^{\circ} \mathrm{C}$ for 1 min, and a final extension at $72^{\circ} \mathrm{C}$ for $5 \mathrm{~min}$. All amplifications included a positive control consisting of HPV 16 DNA extracted from SiHa cells (Ludwig Cancer Research Institute, São Paulo, SP, Brazil) and a negative control consisting of a reaction mixture minus the genomic sample DNA. Amplification products were separated on $1 \%(\mathrm{w} / \mathrm{v})$ agarose gel using Tris/boric acid buffer (TBE, containing $50 \mathrm{mM}$ Tris, $50 \mathrm{mM}$ boric acid, and 2.5 mM EDTA), $\mathrm{pH} 8.4$, and a constant $\operatorname{volt}(3 \mathrm{~V} / \mathrm{cm})$, with a molecular mass marker (4 $\mu \mathrm{g}$ фX174 restriction fragment cleaved with HaeIII) being run simultaneously with the samples. After electrophoresis the gels were stained with ethidium bromide (4.62 ng/ $\mu \mathrm{L}$ ) and HPV or B-globulin fragments visualized under ultraviolet light.

\section{Viral typing}

HPV-positive samples were typed using RFLP according to the method described by Bernard et al. (22). The product of the MY9/ MY11 amplifications was digested with a mixture containing $50 \mathrm{mM}$ Tris- $\mathrm{HCl}, 10 \mathrm{mM}$ $\mathrm{MgCl}_{2}$, and 10 units/ $\mu \mathrm{L}$ of a restriction enzyme in a separate reaction (BamHI, DdeI, HaeIII, HinfI, PstI, RsaI, or Sal3AI (GibcoBRL, Gaithersburg, MD, USA). Fragments of different molecular masses were separated on $7 \%$ polyacrylamide gel $(20.3 \%$ acrylamide, $0.7 \%$ bis-acrylamide, $0.07 \%$ ammonium persulfate and $0.7 \mu \mathrm{L} / \mathrm{mL}$ TBE 10X TEMED (GibcoBR). A sample of undigested amplified sample DNA and $2.5 \mu \mathrm{g}$ standard $\phi X 174$ DNA were run simultaneously in a vertical miniVE electrophoresis cell (Hoefer, San Francisco, CA, USA). After silver staining the fragments were compared with those described by Bernard et al. (22).

\section{Statistical analysis}

Data were analyzed statistically with the Statistical Package for the Social Science (SPSS) version 12.0, using descriptive statistics and the conventional Pearson chisquare test at a pre-fixed $\alpha$ level of 0.05 .

\section{Results}

Of the 99 men studied, 54 (54.5\%) were positive for HPV DNA, and $24.1 \%$ of them presented normal peniscopy, $27.8 \%$ evident clinical lesions (acuminated, pigmented or non-pigmented warts) and $48.1 \%$ isolated lesions consistent with subclinical infection (aceto-white areas, erythematous or macular lesions, papillomas or pearled papules). In the group negative for HPV DNA, 53.3\% presented normal peniscopy, $4.4 \%$ showed 
evident clinical lesions and $42.2 \%$ isolated lesions consistent with subclinical infection (Table 1). The following areas were found to suffer HPV attack: the frenular delta (31.4\%), the preputial mucosa $(29.6 \%)$, the glanspreputial sulcus $(20.4 \%)$, the glans-penis (9.3\%), the penile shaft (7.4\%), and the urethral canal (1.9\%).

Fifty-four of the 74 biopsies examined histologically were from the men shown to be positive for HPV DNA, koilocytosis being found in $27.8 \%$ of these men and constituting the most common histological finding (Table 2). Koilocytosis and other morphological symptoms such as hyperplasia, keratinization or papillomatosis attributed to HPV infection were present in both the HPV DNApositive and -negative groups. Histological

\begin{tabular}{|c|c|c|c|}
\hline \multirow[t]{2}{*}{ Type of lesion } & \multicolumn{3}{|c|}{ Men positive or negative for HPV/DNA } \\
\hline & Positive & Negative & Total \\
\hline Condylomatous lesions ${ }^{1}$ & $15(28 \%)$ & $2(4.5 \%)$ & $17(17 \%)$ \\
\hline Lesions suggestive of infection ${ }^{2}$ & $26(48 \%)$ & $19(42 \%)$ & $45(46 \%)$ \\
\hline Normal & $13(24 \%)$ & $24(53.5 \%)$ & 37 (37\%) \\
\hline Total & $54(100 \%)$ & $45(100 \%)$ & $99(100 \%)$ \\
\hline
\end{tabular}

${ }^{1}$ Acuminated, pigmented or non-pigmented warts. ${ }^{2}$ Aceto-white areas, erythematous or macular lesions, papillomas or pearlized papules.

Table 2. Number and percentage (in parentheses) of men positive or negative for human papillomavirus (HPV) DNA and the histological type of their lesions when examined by biopsy.

\begin{tabular}{lccc}
\hline \multirow{2}{*}{ Histology } & \multicolumn{3}{c}{ Men positive or negative for HPV/DNA } \\
\cline { 2 - 4 } & Positive & Negative & Total \\
\hline Koilocytosis (HPV positive) & $15(28 \%)$ & $5(11 \%)$ & $20(20 \%)$ \\
Lesions suggestive of HPV infection $^{1}$ & $14(26 \%)$ & $13(29 \%)$ & $27(27 \%)$ \\
HPV negative2 & $13(24 \%)$ & $12(27 \%)$ & $25(26 \%)$ \\
Intraepithelial penile lesions & $1(2 \%)$ & - & $1(1 \%)$ \\
No biopsy obtained & $11(20 \%)$ & $15(33 \%)$ & $26(26 \%)$ \\
Total & $54(100 \%)$ & $45(100 \%)$ & $99(100 \%)$ \\
\end{tabular}

${ }^{1}$ Papillomatosis, hyperplasia, keratinization, or hyperkeratosis. ${ }^{2}$ Normal, or chronic non-specific inflammatory process. examination identified in situ carcinoma of the penis in only one tissue sample.

Analysis of the personal data of the 54 men positive for HPV DNA revealed that their mean age was $30.7 \pm 10.3$ years (range: 18-56 years; Table 3 ). There was no significant relationship between the presence of HPV DNA and the following variables: age at first sexual encounter, educational level, frequency of condom use with sexual partners, frequency of condom use with sex workers, marital status, marital stability expressed in years, circumcision, race, sex relationships with sex workers, tobacco use, and previous history of sexually transmitted diseases (Tables 2 and 3). As shown in Table 3 , there was a significant positive correlation between the presence of HPV DNA and number of sexual partners up to the date of the examination $(\mathrm{P}=0.0014)$ and number of sexual partners in the year preceding the survey $(P=0.021)$. The HPV types detected in the study were: HPV 6 (56.1\%), 11 (36.8), $16(3.5 \%), 40(0.7 \%), 61(0.7 \%)$, and 84 $(0.7 \%)$. The DNA from two HPV types, 11 and 84 , was detected in one man.

The most frequently cited sexually transmitted diseases in both the HPV DNA-negative and -positive groups were gonorrhea, acuminated condyloma, syphilis, and genital herpes.

\section{Discussion}

The present study demonstrated that $62.6 \%$ of the sexual partners of women with CIN had condylomatous, macular or papular genital lesions upon peniscopic examination after application of acetic acid (Table 1). Tabrizi et al. (23) studied the sexual partners of women with CIN and found that $38 \%$ of them had clinical lesions and/or lesions identifiable by peniscopy. In our study we found that the areas most affected by genital HPV were the frenular delta and the preputial mucosa, probably because these are the most moist areas and are most subject to micro- 
Table 3. Epidemiological variables investigated in the present study.

\begin{tabular}{|c|c|c|}
\hline \multirow[t]{2}{*}{ Epidemiological variable } & \multicolumn{2}{|c|}{ Men positive or negative for HPV/DNA } \\
\hline & $\begin{array}{l}\text { Positive } \\
(\mathrm{N}=54)\end{array}$ & $\begin{array}{l}\text { Negative } \\
(\mathrm{N}=45)\end{array}$ \\
\hline \multicolumn{3}{|l|}{ Age } \\
\hline$\leq 19$ & $5(9.3 \%)$ & $2(4.4 \%)$ \\
\hline$\geq 20$ to $\leq 29$ & $23(42.6 \%)$ & $19(42.2 \%)$ \\
\hline$\geq 30$ to $\leq 39$ & $16(29.6 \%)$ & $9(20.0 \%)$ \\
\hline$\geq 40$ to $\leq 49$ & $6(11.1 \%)$ & $14(31.1 \%)$ \\
\hline$\geq 50$ to $\leq 59$ & $4(7.4 \%)$ & $1(2.2 \%)$ \\
\hline Mean age for HPV-positive men $(30.7 \pm 10.3$ years $)$ & - & - \\
\hline Mean age for HPV-negative men $(33.0 \pm 9.5$ years $)$ & - & - \\
\hline \multicolumn{3}{|l|}{ Age at first intercourse } \\
\hline$\leq 16$ & $43(79.6 \%)$ & $26(57.8 \%)$ \\
\hline$\geq 17$ to $\leq 20$ & $10(18.5 \%)$ & $17(37.8 \%)$ \\
\hline$\geq 21$ to $\leq 30$ & $1(1.9 \%)$ & $2(4.4 \%)$ \\
\hline Mean age for HPV-positive men $(15.5 \pm 2.8$ years $)$ & - & - \\
\hline Mean age for HPV-negative men (16.2 \pm 2.6 years) & - & - \\
\hline \multicolumn{3}{|l|}{ Circumcision } \\
\hline Circumcised & $7(13.0 \%)$ & $3(6.7 \%)$ \\
\hline Uncircumcised & $47(87.0 \%)$ & $42(93.3 \%)$ \\
\hline \multicolumn{3}{|l|}{ Condom use with female sex workers } \\
\hline Never & $4(16.0 \%)$ & $6(28.6 \%)$ \\
\hline Sometimes & $5(20.0 \%)$ & 7 (33.3\%) \\
\hline Frequently & $5(20.0 \%)$ & $2(9.5 \%)$ \\
\hline Always & $11(44.0 \%)$ & $6(28.6 \%)$ \\
\hline \multicolumn{3}{|l|}{ Condom use with sexual partner } \\
\hline Never & $31(57.4 \%)$ & $28(62.2 \%)$ \\
\hline Sometimes & $15(27.8 \%)$ & $15(33.3 \%)$ \\
\hline Frequently & $4(7.4 \%)$ & $1(2.2 \%)$ \\
\hline Always & $4(7.4 \%)$ & $1(2.2 \%)$ \\
\hline \multicolumn{3}{|l|}{ Educational level } \\
\hline Illiterate & $1(1.9 \%)$ & $1(2.2 \%)$ \\
\hline Primary school (complete or incomplete) & $32(59.2 \%)$ & $1(2.2 \%)$ \\
\hline Secondary school (complete or incomplete) & $18(33.4 \%)$ & $13(28.9 \%)$ \\
\hline University (complete or incomplete) & $3(5.6 \%)$ & $5(11.1 \%)$ \\
\hline \multicolumn{3}{|l|}{ Marital status } \\
\hline Single & $9(16.7 \%)$ & $8(17.8 \%)$ \\
\hline Married & $28(51.9 \%)$ & $27(60 \%)$ \\
\hline Cohabiting & $17(31.5 \%)$ & $10(22.2 \%)$ \\
\hline \multicolumn{3}{|l|}{ Marital stability (number of years married) } \\
\hline$\geq 1$ to $\leq 2$ & $23(42.6 \%)$ & $16(35.6 \%)$ \\
\hline$\geq 3$ to $\leq 5$ & $10(18.5 \%)$ & $7(15.6 \%)$ \\
\hline$\geq 6$ & $22(40.7 \%)$ & $22(48.9 \%)$ \\
\hline Mean for HPV-positive men ( $6.7 \pm 7.4$ years $)$ & - & - \\
\hline Mean for HPV-negative men ( $9.1 \pm 8.2$ years $)$ & - & - \\
\hline
\end{tabular}


Table 3 continued.

\begin{tabular}{|c|c|c|}
\hline \multirow{2}{*}{ Epidemiological variable } & \multicolumn{2}{|c|}{ Men positive or negative for HPV/DNA } \\
\hline & $\begin{array}{l}\text { Positive } \\
(\mathrm{N}=54)\end{array}$ & $\begin{array}{c}\text { Negative } \\
(\mathrm{N}=45)\end{array}$ \\
\hline \multicolumn{3}{|l|}{ Race } \\
\hline White & $46(85.2 \%)$ & $42(93.3 \%)$ \\
\hline Non-white & $8(14.8 \%)$ & $3(6.7 \%)$ \\
\hline \multicolumn{3}{|l|}{ Sexual intercourse with female sex workers } \\
\hline Yes & $2546.3 \%)$ & $21(46.7 \%)$ \\
\hline No & $29(53.7 \%)$ & $24(53.3 \%)$ \\
\hline \multicolumn{3}{|l|}{ Sexual partners up to the date of the survey } \\
\hline$\geq 1$ to $\leq 10$ & $22(40.7 \%)$ & $27(60.0 \%)$ \\
\hline$\geq 11$ to $\leq 50$ & $27(50.0 \%)$ & $18(40.0 \%)$ \\
\hline$\geq 51^{*}$ & $5(9.3 \%)$ & - \\
\hline \multicolumn{3}{|l|}{ Mean for HPV-positive men $(23.5 \pm 22.5)^{*}$} \\
\hline \multicolumn{3}{|l|}{ Mean for HPV-negative men $(14.1 \pm 12.1)^{*}$} \\
\hline \multicolumn{3}{|c|}{ Sexual partners in the year preceding the survey } \\
\hline 1 & $33(61.1 \%)$ & $35(77.8 \%)$ \\
\hline$\geq 2$ & $21(38.9 \%)$ & $10(22.2 \%)$ \\
\hline Mean for HPV-positive men (2.2 \pm 1.4$)$ & - & - \\
\hline Mean for HPV-negative men $(2.1 \pm 0.9)$ & - & - \\
\hline \multicolumn{3}{|l|}{ Sexually transmitted diseases ${ }^{1}$} \\
\hline None & $36(66.7 \%)$ & $31(68.9 \%)$ \\
\hline Gonorrhea & $10(18.5 \%)$ & $8(17.8 \%)$ \\
\hline Condyloma & $5(9.3 \%)$ & $4(8.9 \%)$ \\
\hline Syphilis & $2(3.7 \%)$ & - \\
\hline Hepatitis & $1(1.9 \%)$ & $1(2.2 \%)$ \\
\hline Genital herpes & $1(1.9 \%)$ & $3(6.7 \%)$ \\
\hline Soft chancre & $1(1.9 \%)$ & - \\
\hline Chlamydial urethritis & $1(1.9 \%)$ & - \\
\hline \multicolumn{3}{|l|}{ Smoking } \\
\hline Non-smokers & $32(59.3 \%)$ & $29(64.4 \%)$ \\
\hline$<10$ cigarettes per day & $7(13.0 \%)$ & $4(8.9 \%)$ \\
\hline$\geq 10$ cigarettes per day & $15(27.8 \%)$ & $12(26.7 \%)$ \\
\hline
\end{tabular}

Data are reported as number and percentage (in parentheses) of men positive or negative for human papillomavirus (HPV). ${ }^{1}$ The same individual sometimes gave more than one response to this question. ${ }^{*} \mathrm{P}<0.05$ indicates a statistically significant difference between the positive and negative groups by Pearson's chi-square test.

traumas during sexual activity.

The collection of material followed by peniscopy was justified by the possibility of working with minimum amounts of viral DNA in the penile samples obtained through scrapings, which might imply false-negative results for DNA/HPV, although the collection covers the areas that are most affected by HPV $(6,24,25)$. The study cannot infer the percentage of false-negative results for DNA/HPV, but false-negative results could be explained by 1) the limitations of brush use to obtain the sample (coverage of scraped areas, pressure applied to perform the scraping, and the limitation of the brush itself in obtaining the sample); 2) by the limited 
amount of human cells contained in the sample; 3) by the amplification technique used for the b-globin, and 4) the presence of inhibitors or the technique used to extract DNA. Studies comparing different sampling methods must be performed and the method used to extract human and viral genetic material should be improved.

Koilocytosis was the most frequent histological finding $(27.8 \%)$ in the men who were positive for HPV DNA (Table 2). Hippeläinen et al. (24) found that $53.7 \%$ of a group of HPV DNA-positive men exhibited koilocytosis, while Nicolau et al. (26) using the same methodology, found a $50 \%$ frequency of koilocytosis. The results of our study did not allow us to infer that koilocytosis is a pathognomonic characteristic of HPV infection of the male urinogenital area because there were as many false-positives as false-negatives, a fact which may lead to false information being given to the patient.

The mean age of our group of men who showed HPV DNA was 30.7 years (Table 3 ), as compared to the mean of 38 years in the study by Bleeker et al. (27) and 26.5 years in the study by Baken et al. (28), although the case-controlled study carried out in different countries by Franceschi et al. (29) showed no association between age and HPV infection.

With respect to educational level (Table 3 ), our sample may not have been representative of all HPV-contaminated males in the city of Caxias do Sul and it is quite possible that men with completed secondary or higher education would have better access to more reliable information on the disease they were infected with and were also able to attend private clinics for treatment. All the men in the group positive for HPV DNA had only basic or secondary education and belonged to the segment of society that has least access to information and whose only access to medical assistance is via the public health service. These data suggest that health education is very precarious and that an epide- miological survey should be conducted to ascertain what level of sex education this group of men receives in school and at home.

There was no association between marital status of the men and the presence of HPV DNA (Table 3). The study of the association between marital stability $\geq 6$ years and marital status revealed the presence of HPV DNA in $12.5 \%$ of single men, in $23.5 \%$ of cohabiting men and in $60.7 \%$ of married men. There was a statistically significant $(\mathrm{P}$ $=0.025)$ association between the presence of HPV DNA in married males and in males with marital stability $\geq 6$ years.

The age at first sexual encounter (Table 3) showed that $79.6 \%$ of HPV DNA-positive men had initiated sexual activity when they were $\leq 16$ years old, but this was not statistically significant. In a 2002 study of men in the US, Castellsagué et al. (30) found that $22.9 \%$ of uncircumcised men had their first sexual experience when they were less than 16 years old while only $4.2 \%$ of circumcised men had their first sexual experience at this age. Colombian and Spanish males were the subjects of a study published in 1997 by Castellsagué et al. (31), who found that 20.1\% of males had their first sexual encounter when they were less than 15 years old, while Franceschi et al. (29) found that $16 \%$ of males had their first sexual encounter at $\leq 16$ $(\mathrm{P}=0.67)$. In our study, men in the HPV DNA-positive group had their first sexual encounter at a mean age of 15.5 years but there was no statistically significant association between the presence of HPV DNA and age at first sexual encounter. Hippeläinen et al. (25) published an epidemiological study which showed that Finnish males had their first sexual encounter when they were $16.2 \pm$ 1.5 years old. Rotola et al. (5) showed that the mean age at which Italian males in the city of Bologna had their first sexual encounter was 18 years.

Our data indicate that in the group of men studied the greatest risk factor $(\mathrm{P}=0.038)$ for acquiring HPV DNA was intimately re- 
lated to the total number of sexual partners up to the date of the survey, with men who had the highest number of sexual partners also having the highest risk $(\mathrm{P}=0.038)$ of being positive for HPV DNA (Table 3). Castellsagué et al. (30) studied uncircumcised men who had had less than five sexual partners up to the time of the study and found that $12.5 \%$ of them were positive for HPV DNA, while among men who had had more than five sexual partners up to the time of the study the percentage of HPV DNApositive subjects increased to $44.7 \%$. Franceschi et al. (29) found a highly significant association $(\mathrm{P}<0.01)$ between the presence of HPV DNA and the number of sexual partners up to the date of the study, with $21.1 \%$ of men having less than 10 sexual partners being positive for HPV DNA, as opposed to $43.3 \%$ of men having more than 10 sexual partners.

The number of sexual partners in the year preceding our study (Table 3) was a highly significant $(\mathrm{P}=0.021)$ variable concerning the presence of HPV DNA; however, this variable has not been previously evaluated by researchers in this area. The results obtained show us that the higher number of sexual partners is correlated to higher risks of being HPV DNA positive.

We found that for the shortest period of marital stability ( $\geq 1$ to $\leq 2$ years) $42.6 \%$ of subjects were positive for HPV DNA and for the highest period of marital stability ( $\geq 6$ years) $40.7 \%$ of the subjects were positive. Both the minimum and maximum marital stability showed the highest percentages of HPV DNA-positive men (Table 3). In their 1993 study, Hippeläinen et al. (25) found that $68.2 \%$ of men who had had stable relationships for up to 2 years were positive for HPV DNA, while only $31.7 \%$ of men who had had stable relationships for more than two years were HPV DNA positive. These results were also not statistically significant.

The analysis showed that $59.3 \%$ of HPV DNA-positive males smoked tobacco (Table
3). However, as previously observed by Rotola et al. (5), Hippeläinen et al. (24,25), Franceschi et al. (29), and Wikstrom et al. (32), no significant correlation was observed between smoking and HPV positiveness in males. The absence of correlation between smoking and HPV infection in males, and the positive correlation observed in females (33) can be considered as an indicative that tobacco smoking, local immunity and the different structure of epithelial tissue of the female genital tract favor infection by HPV in females and the genesis of precursor and invasive lesions in the neck of the uterus.

Of the men in our HPV DNA group, 13\% were circumcised, but there was no statistically significant association between circumcision and HPV DNA infection (Table 3). Castellsagué et al. (30) studied 292 circumcised and 847 uncircumcised men in different countries and found that $5.5 \%$ of circumcised and $19.6 \%$ of uncircumcised men were infected with HPV, and found an association between male circumcision and a reduced risk of genital infection with HPV. There is a reduced risk of cervical cancer in women with circumcised sexual partners, but with a high risk of HPV infection for the women.

We found that $46.3 \%$ (not significant) of the HPV DNA-positive group of males in our study had sexual intercourse with female sex workers (Table 3). Franceschi et al. (29) found that $57.6 \%$ (not significant) of their sample of males had sexual contact with female sex workers, while Castellsagué et al. (30) reported that $20.4 \%$ of their sample of males had such relationships and Castellsagué et al. (31) cited that $41.6 \%$ of Spanish and $61.4 \%$ of Colombian men had sexual contact with female sex workers. In our study, the lack of association between previous contact with female sex workers and HPV infection may be explained by the fact that our sample was relatively small. During the epidemiological interviews with the men it was noted that the majority of the 65 men who admitted to having had contact with 
female sex workers mentioned that their contact was casual and in the past. It is known that female sex workers have a higher risk of acquiring and disseminating sexually transmitted diseases because they have a greater number of sexual partners. To clarify this question, there is the need for a more elaborate epidemiological study in which this variable and other aspects of sexual behavior are surveyed in more detail.

About $84 \%$ of the HPV DNA-positive group used condoms (sometimes, frequently or always) during sexual activity with female sex workers but this was not statistically significant (Table 3). Franceschi et al. (29), in a similar Brazilian study, found that condom use was $86 \%$ and that $37 \%$ of the men studied in different countries regularly used condoms during sexual intercourse with female sex workers and demonstrated that the HPV-negative group made better use of condoms in sexual relationships with female sex workers. Although our study did not confirm the important protective role of condoms, this factor in itself indicates the possible existence of other unidentified epidemiological or behavioral risk factors in the male population infected with HPV and that new epidemiological studies on condom use are needed to better understand our results. In our study, $57 \%$ of the HPV DNApositive men never used condoms with their regular female (non-sex worker) partner while $62.2 \%$ of HPV DNA-negative men never used a condom under the same circumstances (Table 3). Hippeläinen et al. (25) pointed out the importance of condoms as a protective factor against HPV infection.

We found that a previous history of sexually transmitted disease in the HPV DNApositive group (33.3\%) was not statistically significant (Table 3). Wikstrom et al. (32) found that $23 \%$ (not significant) of males studied had previously had a sexually transmitted disease, while Hippeläinen et al. (24) reported an incidence of $15.8 \%$. In our study the sexually transmitted diseases most fre- quently reported by both groups were (in decreasing order) gonorrhea, acuminated condyloma, syphilis, and genital herpes but there was no statistically significant association between a history of sexually transmitted disease and the presence or absence of HPV DNA. Hippeläinen et al. (24) detected Chlamydia infection and gonorrhea in their study.

Our study demonstrated for the first time that there is an association between the mean number of female sexual partners in the year preceding the study and the presence of HPV DNA, strengthening the belief that the higher the number of sexual partners the greater the chance of acquiring and transmitting HPV.

The percentage of the different types of HPV identified in our study was: HPV $6=$ $56.1 \%$; HPV $11=36 \%$; HPV $16=3.5 \%$; HPV $40=0.7 \% ; \mathrm{HPV} 61=0.7 \%$, and HPV $84=0.7 \%$, with one man being doubly infected. Paesi et al. (34) carried out a prospective study of women carrying CIN from August to December 2000 at the same institution as surveyed in the present study. They found that the most prevalent HPV types were 16 and 18 compared with 6 and 11 in the present study. Franceschi et al. (29) conducted a case-controlled study of the sexual partners of women with in situ carcinomas and invasive carcinomas of the neck of the uterus and found that the most prevalent HPV types were $16,18,31$, and 33 which are at high risk of being oncogenic. Castellsagué et al. (31) studied couples infected with HPV but found little agreement between the types of HPV virus identified (31.8\%). These conflicting results are probably related to the different diagnostic methodology used in these studies. Tabrizi et al. (23) studied benign histological samples from HPV-infected tissues from the sexual partners of women who had cervical tissue with cytopathological changes suggestive of HPV infection or who had lesions which could be considered to be precursors of cervical cancer and found that 
$73 \%$ of the viruses encountered were types 6 and 11 .

The results of the present study are consistent with the epidemiological data available in the literature, except for our data on the number of female sexual partners up to the time of the study ("lifetime sexual partners') or the number of female sexual partners in the year preceding the study and HPV infection. HPV infection was frequent in the male sexual partners of women with CIN, indicating that a systematic study of this population is needed so that these couples can be better informed.

Our results, taken together with literature data, show that there is little agreement between the prevalence of infection with HPV in men at high risk of HPV infection and women carrying high and low grade lesions of the neck of the uterus. This may be explained by the different levels of biological activity and differences in local immunity and organization of the genital epithelia of each sex. These factors can favor viral transmission and multiplication and predispose both sexes towards infection with one or more viruses. The different levels of biological activity and differences in local immunity and organization of the genital epithelia of each sex indicate that a prospective study is needed using samples of genital epithelia collected from a reasonable number of sexual partners. Thus, a more detailed epidemiological study can be carried out to gather more information on the biological behavior of infection by human papillomavirus.

\section{References}

1. Howley PM \& Lowy DR (2001). Papillomaviruses and their replication. In: Knipe DM \& Howley PM (Editors), Fields Virology. 4th edn. Lippincott Williams \& Wilkins Publishers, New York, 2197-2229.

2. WHO (1995). IARC Working Group on the evaluation of carcinogenic risks to humans. Human papillomaviruses (HPV). Summary of data reported and evaluation, 64. WHO, Basel, Switzerland.

3. Menzo S, Monachetti A, Trozzi C et al. (2001). Identification of six putative novel human papillomaviruses (HPV) and characterization of candidate HPV type 87. Journal of Virology, 75: 11913-11919.

4. de Villiers E, Fauquet C, Broker T et al. (2004). Classification of papillomaviruses. Journal of Virology, 324: 17-27.

5. Rotola A, Costa S, Monini P et al. (1994). Impact of sexual habits on the clinical evaluation of male HPV infection. European Journal of Epidemiology, 10: 373-380.

6. Siegel JF \& Mellinger BC (1992). Human papillomavirus in the male patient. Urologic Clinics of North America, 19: 83-91.

7. Brown T, Yen-Moore A \& Tyring S (1999). An overview of sexually transmitted diseases. Part II. Journal of the American Academy of Dermatology, 41 (Part 1): 661-677; quiz 678-680.

8. Kotoulas IG, Cardamakis E, Relakis K et al. (1996). Penoscopic diagnosis of flat condyloma and penile intraepithelial neoplasia. IV. Urethral reservoir. Gynecologic and Obstetric Investigation, 41: 5560.

9. Wikstrom A, Hedblad M, Johansson B et al. (1992). The acetic acid test in evaluation of subclinical genital papillomavirus infection: a comparative study on penoscopy, histopathology, virology and scanning electron microscopy findings. Genitourinary Medicine, 68: 90-99.

10. Law C, Qassim M, Thompson C et al. (1991). Factors associated with clinical and sub-clinical anal human papillomavirus infection in homosexual men. Genitourinary Medicine, 67: 92-98.
11. Mandal D, Haye K, Ray T et al. (1991). Prevalence of occult human papillomavirus infection, determined by cytology and DNA hybridization, in heterosexual men attending a genitourinary medicine clinic. International Journal of STD and AIDS, 2: 351-355.

12. Nuovo GJ, Hochman HA, Eliezri YD et al. (1990). Detection of human papillomavirus DNA in penile lesions histologically negative for condylomata. Analysis by in situ hybridization and the polymerase chain reaction. American Journal of Surgical Pathology, 14: 829-836.

13. Omar R, Choudhury M, Fischer J et al. (1991). A "Pap" test for men? Male urethral smears as screening tool for detecting subclinical human papillomavirus infection. Journal of Urology, 37: 110-115.

14. Wikstrom A, Lidbrink P, Johansson B et al. (1991). Penile human papillomavirus carriage among men attending Swedish STD clinics. International Journal of STD and AIDS, 2: 105-109.

15. Ji H, Yliskoski M, Vayrynen M et al. (1991). Colposcopic analysis of genital human papillomavirus infections during an 8-year prospective follow-up. International Journal of Gynecology and Obstetrics, 36: 291-300.

16. Levine R, Crum C, Herman E et al. (1984). Cervical papillomavirus infection and intraepithelial neoplasia: a study of male sexual partners. International Journal of Gynecology and Obstetrics, 64: 16-20.

17. Sand P, Bowen L, Blischke S et al. (1986). Evaluation of male consorts of women with genital human papilloma virus infection. International Journal of Gynecology and Obstetrics, 68: 679-681.

18. Schneider A, Kirchmayr R, De Villiers E et al. (1988). Subclinical human papillomavirus infections in male sexual partners of female carriers. Journal of Urology, 140: 1431-1434.

19. Bauer HM, Ting Y, Greer CE et al. (1991). Genital human papillomavirus infection in female university students as determined by a PCR-based method. Journal of the American Medical Association, 
265: 472-477.

20. Hildesheim A, Schiffman M, Gravitt P et al. (1994). Persistence of type-specific human papillomavirus infection among cytologically normal women. Journal of Infectious Diseases, 169: 235-240.

21. Saiki R, Gelfand D, Stoffel S et al. (1988). Primer-directed enzymatic amplification of DNA with a thermostable DNA polymerase. Science, 239: 487-491.

22. Bernard H, Chan S, Manos M et al. (1994). Identification and assessment of known and novel human papillomaviruses by polymerase chain reaction amplification, restriction fragment length polymorphisms, nucleotide sequence, and phylogenetic algorithms. Journal of Infectious Diseases, 170: 1077-1085.

23. Tabrizi SN, Tan J, Quinn M et al. (1992). Detection of genital human papillomavirus (HPV) DNA by PCR and other conventional hybridisation techniques in male partners of women with abnormal Papanicolaou smears. Genitourinary Medicine, 68: 370-373.

24. Hippeläinen M, Yliskoski M, Saarikoski S et al. (1991). Genital human papillomavirus lesions of the male sexual partners: the diagnostic accuracy of peniscopy. Genitourinary Medicine, 67: 291-296.

25. Hippeläinen M, Syrjanen S, Koskela H et al. (1993). Prevalence and risk factors of genital human papillomavirus (HPV) infections in healthy males: a study on Finnish conscripts. Sexually Transmitted Diseases, 20: 321-328.

26. Nicolau SM, Martins NV, Ferraz PE et al. (1997). Importance of peniscopy, oncologic cytology and histopathology in the diagnosis of penile infection by human papillomavirus. Revista Paulista de Medicina, 115: 1330-1335.

27. Bleeker MC, Hogewoning CJ, Van Den Brule AJ et al. (2002). Penile lesions and human papillomavirus in male sexual partners of women with cervical intraepithelial neoplasia. Journal of the American Academy of Dermatology, 47: 351-357.

28. Baken LA, Koutsky LA, Kuypers J et al. (1995). Genital human papillomavirus infection among male and female sex partners: prevalence and type-specific concordance. Journal of Infectious Diseases, 171: 429-432.

29. Franceschi S, Castellsague X, Dal Maso L et al. (2002). Prevalence and determinants of human papillomavirus genital infection in men. British Journal of Cancer, 86: 705-711.

30. Castellsagué X, Bosch FX, Munoz N et al. (2002). Male circumcision, penile human papillomavirus infection, and cervical cancer in female partners. New England Journal of Medicine, 346: 11051112.

31. Castellsagué X, Ghaffari A, Daniel RW et al. (1997). Prevalence of penile human papillomavirus DNA in husbands of women with and without cervical neoplasia: a study in Spain and Colombia. Journal of Infectious Diseases, 176: 353-361.

32. Wikstrom A, Popescu C \& Forslund O (2000). Asymptomatic penile HPV infection: a prospective study. International Journal of STD and AIDS, 11: 80-84.

33. Villa LL (1997). Human papillomaviruses and cervical cancer. Advances in Cancer Research, 71: 321-341.

34. Paesi SO, Serafini EP \& Madi SRC (2003). Determinação e tipagem do papillomavirus humano (HPV) em amostras de população feminina atendida no Ambulatório de Patologia Cervical do Ambulatório Central da Universidade de Caxias do Sul. Revista de Ciências Médicas da Universidade de Caxias do Sul e da Associação Médica de Caxias do Sul, 2: 16-22. 